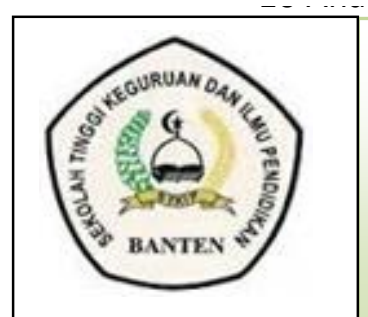

JoEE 2 (1) (2021) : 24-38

JoEE

(Journal of Earlychildhood Education)

JURNAL PENDIDIKAN GURU PENDIDIKAN ANAK USIA DINI

http://jurnal.stkipbanten.ac.id/index.php/Joe

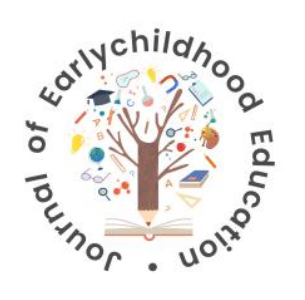

\title{
EFEKTIVITAS PENGGUNAAN MEDIA STICK POUCH (KANTONG STIK) SEBAGAI MEDIA PENGEMBANGAN KEMAMPUAN KOGNITIF MENGENAL KONSEP BILANGAN 1-10 ANAK TK
}

\author{
Larasati Nur Indah Prawesti ${ }^{1}$ dan Mustika Dewi ${ }^{2}$ \\ ${ }^{1}$ Dosen Sekolah Tinggi Keguruan dan Ilmu Pendidikan Banten \\ ${ }^{2}$ Mahasiswa Pendidikan Guru Pendidikan Anak Usia Dini \\ Penulis Korespondensi:, iiazzprawesti@gmail.com ${ }^{1}$, dewimustika@mail.com² \\ Artikel: Pengembangan Keampuan Kognitif Anak Usia Dini \\ Penerima: Januarir, 2021 \\ Diterima: Februari, 2021 \\ Dipublikasikan: Maret, 2021
}

\begin{abstract}
To carry out learning using learning media in the form of stick pouch media so that children can easily recognize numbers 1-10 correctly. The research that the writer did is a literature study research. The research used is descriptive research with a qualitative approach. Based on several source that have been compiled by writer, it can been seen that the use of stick pouch media to improve children's cognitive abilities in recognizing numbers 1-10 significantly increased, that is from $37.69 \%$ before using this media and up to $60.45 \%$ after using the snowball throwing cooperative learning model, then up again to $86.23 \%$ in the last cycle, so there was an increase of $61.46 \%$.
\end{abstract}

Keywords: Stick Pouch, Congnitive, Number Concept

\begin{abstract}
ABSTRAK
Melaksanakan pembelajaran dengan menggunakan media pembelajaran berupa media stick pouch (kantong stik) agar anak mampu dengan mudah mengenal angka 1-10 dengan benar. Penelitian yang peneliti lakukan ini berupa penelitian studi literature atau studi kepustakaan. Penelitian yang digunakan adalah penelitian deskriptif dengan pendekatan kualitatif. Berdasarkan dari berbagai sumber yang berhasil dihimpun oleh peneliti, dapat dilihat bahwa penggunaan media kantong stik untuk meningkatkan kemampuan kognitif anak dalam mengenal bilangan 1-10 meningkatkan secara signifikan, yaitu dari $37.69 \%$ sebelum menggunakan media stik angka dengan kantong stik tersebut naik menjadi $60.45 \%$ setelah menggunakan media stik angka dengan kantong stik, dan naik lagi menjadi $86.23 \%$ pada siklus terakhir, sehingga terjadi peningkatan sebesar rata-rata $61.46 \%$.
\end{abstract}

Kata Kunci: kantong stik, kognitif, konsep bilangan 


\section{PENDAHULUAN}

Peran guru di lembaga pendidikan sekolah, amatlah sangat penting bagi siswasiswi. Tanpa adanya peran guru, proses pembelajaran disekolah tidak akan sempurna, apalagi di zaman modern ini dimana semuanya sudah serbah canggih, guru di zaman modern ini juga dituntut menjadi guru yang memiliki tingkat kreativitas dan ide-ide yang menarik dalam melaksanakan pembelajaran di dalam kelas. Apalagi pada pembelajaran matematika, pada kenyataan yang ada matematika sangat jarang diminati oleh siswa, hal itu karna mereka menganggap matematika itu sulit dan membosankan. Guru sebagai fasilitator dalam proses pembelajaran di sekolah dituntut untuk memberikan pengalaman kepada peserta didik. Dalam proses belajar di sekolah tidak lagi hanya mengetahui teori-teori, tetapi mendapat pengalaman nyata. Peserta didik dituntut untuk aktif dalam proses pembelajaran, mampu mengemukakan pendapatpendapatnya, serta mampu memecahkan masalah-masalah yang disajikan dalam proses pembelajaran.

Keberhasilan dalam pembelajaran menjadi tujuan setiap guru, baik pada pendidikan formal maupun non formal. Kegiatan belajar mengajar yang melahirkan interaksi unsur-unsur manusiawi adalah sebagai suatu proses dalam rangka mencapai tujuan pengajaran.

Pendidikan Anak Usia Dini (PAUD) memilki 6 aspek perkembangan, yaitu: agama dan moral, fisik motorik, kognitif, bahasa, sosial emosional, dan seni. Keenam aspek tersebut sangat berpengaruh terhadap perkembangan anak usia dini, salah satunya adalah kemampuan mengenal angka tarhadap anak usia dini.

\footnotetext{
${ }^{1}$ Kurniawan, Agus Prasetyo. (2014). Strategi Pembelajaran Matematika. Surabaya: UIN Sunan Ampel Press. Hal.1

(C) 2021, JoEE, Jurnal of Early Childhood. PGPAUD e-ISSN: 2775-7870
}

Mengenal angka bagi anak usia dini merupakan hal yang penting untuk belajar memulai mengenal masalah dan juga mengenal dunia matematika. Matematika merupakan salah satu disiplin ilmu yang memiliki kekhasan dibandingkan dengan ilmu yang lain. Menyadari pentingnya matematika dalam kehidupan manusia maka diseluruh dunia termasuk Indonesia matematik atau muatan matematika di ajarkan di tingkat sekolah. Hal ini dilakukan agar sejak dini bisa mengasah logika berpikirnya untuk bekal untukkehidupan bermasyarakat kelak. Selain itu pemahaman terhadap materi matematika di sekolah akan menunjang pemahaman materi mata pelajaran lain yang menggunakan muatan-muatan matematika. ${ }^{1}$

Apabila kita ingin mengajarkan sesuatu kepada anak/siswa dengan baik dan berhasil pertama-tama yang harus diperhatikan adalah metode atau cara pendekatan yang akan dilakukan, sehingga sasaran yang diharapkan dapat tercapai atau terlaksana dengan baik, karena metode atau cara pendekatan yang dalam fungsinya merupakan alat untuk mencapai tujuan. $^{2}$

Oleh karena itu perlu adanya media pembelajaran. Media pembelajaran digunakan sebagai alat untuk menyampaikan materi pembelajaran pada siswa. Berbagai bentuk media dapat digunakan untuk meningkatkan pengalaman belajar ke arah yang lebih konkret. Pengajaran dengan menggunakan media tidak hanya sekedar menggunakan kata-kata (simbol verbal), sehingga dapat diharapkan diperolehnya hasil pengalaman belajar yang lebih berarti bagi siswa.

Sementara itu, untuk mendukung proses pembelajaran dengan menggunakan

\footnotetext{
2 Simanjutak, Lisnawati, dkk. (1993). Metode Mengajar Matematika 1. Jakarta: PT Rineka Cipta. Hal.8o
}

PGPAUD JURNAL 
Larasati Nur Indah Prawesti dan Mustika Dewi. Efektivitas Penggunaan Media Stick Pouch (Kantong Stik) Sebagai Media Pengembangan Kemampuan Kognitif Mengenal Konsep Bilangan 1-10 Anak $\mathrm{Tk}$

metode bermain, diperlukan suatu media yang dapat meningkatkan kualitas anak dalam mengenal angka dengan mudah dan benar. Syaiful Bahri (1995: 136) menjelaskan di dalam kegiatan belajar mengajar ketidakjelasan bahan yang disampaikan dapat dibantu dengan menghadirkan media sebagai perantara. Kerumitan bahan pelajaran dapat disederhanakan dengan bantuan media. Media dapat mewakili apa yang kurang mampu guru ucapkan melalui kata-kata atau kalimat.

Media pembelajaran sebenarnya memiliki fungsi yang penting, selain berfungsi membantu pemahaman siswa terhadap materi yang nantinya dapat mempengaruhi hasil belajarnya, media pembelajaran juga berfungsi sebagai pengganti seorang guru ketika guru tdak dapat memberikan materi kepada siswa karna suatu hal. ${ }^{3}$

Dengan menggunakan media, diharapkan pembelajaran dikelas menjadi lebih mudah di pelajari. Penggunaan media pembelajaran matematika di sekolah diantaranya yaitu menggunakan media yang berupa media stick pouch (kantong stik), apalagi pada pembelajaran matematika di sekolah dasar peserta didik masih senangnya bermain, bahkan dunia mereka adalah dunia bermain. Apalagi pada pembelajaran matematika yang dianggap sebagai pelajaran yang menakutkan, dengan menggunakan media pembelajaran hal itu bisa menjadikan proses pembelajaran lebih bervariasi dan tidak menakutkan.

Peran guru dalam pembelajaran amatlah kuat dan penting, bahkan peran guru sangat didukung oleh kekuatan konsep untuk mengembangkan metode-metode dan media pembelajaran. Pada

\footnotetext{
${ }^{3}$ Uchi Nur Uzzlifatul Choiroh. (2019). Peningkatan Kemampuan Berhitung Siswa Menggunakan Media Stick Pouch Materi Perkalian Dan Pembagian Kelas li Mi At Taqwa Kraton Pasuruan. Skripsi Program Studi (C) 2021, JoEE, Jurnal of Early Childhood. PGPAUD e-ISSN: 2775-7870
}

pembelajaran matematika zaman dahulu, murid hanya mengandalkan buku yang diberikan oleh sekolah dan guru yang hampir 90\% menerangkan peserta didik dan peserta didik mendengarkan, pengetahuan murid terbatas, dan sekolah hanya membekali dengan teori-teori pengetahuan saja, bukan dari pengetahuan yang diperoleh dari hasil belajar mereka sendiri.

Menurut Dimyati dan Mudjiono (2006), salah satu faktor intern yang mempengaruhi hasil belajar siswa adalah sikap terhadap belajar. Sikap siswa terhadap proses belajar dapat berupa penerimaan, penolakan, atau pengabaian kesempatan belajar. Pada kondisi pembelajaran yang masih menerapkan pembelajaran konvensional, siswa cenderung melakukan pengabaian terhadap kesempatan untuk belajar. Hal tersebut tentu berpengaruh pada hasil belajarnya. 4

Dari hasil observasi yang dilakukan di TK Insan Syazani kelompok B diperoleh hasil bahwa tidak semua peserta didik mengenal angka 1-10 dengan benar. Hal ini terlihat ketika peserta didik mampu berhitung 1-10 namun masih belum tahu angkanya. Kebanyakan anak hanya menghafal tanpa mengetahui angkanya. Mengenal angka adalah suatu kemampuan kognitif anak, dalam pengembangan kognitif ini bertujuan mengembangkan kemampuan di bidang berfikir anak, membantu mengembangkan kemampuan mengenal angka. Namun untuk menstimulus agar anak mampu mengembangkan kemampuan mengenal angka tidaklah semudah yang kita bayangkan karena harus melalui proses yang panjang. Untuk pengenalan angka 110 pada anak usia dini harus menggunakan

PGMI. Dakultas Tarbiyah dan Keguruan. UIN Sunan Ampel Surabaya. Tidak Terbit. Hal.4

4 Dimyati \& Mudjiono. 2013. Belajar dan

Pembelajaran. Jakarta: Rineka Cipta. Hal.239

PGPAUD JURNAL 
metode yang baik dan menggunakan caracara yang menarik agar anak dapat betulbetul memahami angka dengan baik dan benar, oleh sebab itu pengembangan yang paling tepat umgtuk merangsang perkembangan pengenalan angka 1-10 harus menstimulus anak dengan benar.

Beberapa kemungkinan penyebab kurangnya kemampuan berhitung peserta didik pada materi perkalian dan pembagian yaitu: (1) guru cenderung hanya menerapkan metode ceramah, (2) kurang kreatifnya guru dalam proses pembelajaran, sehingga siswa kurang terlibat dan aktif secara keseluruhan, (3) media yang digunakan guru kurang menarik, (4) pembelajaran matematika yang terkesan jenuh dan menakutkan.

Untuk mengatasi permasalahan tersebut, maka perlu diadakannya media yang dapat meningkatkan kemampuan mengenal angka terhadap anak usia dini. Salah satu alternatif untuk memecahkan masalah tersebut adalah melaksanakan pembelajaran dengan menggunakan media pembelajaran berupa media stick pouch (kantong stik) agar anak mampu dengan mudah mengenal angka 1-10 dengan benar.

Media stick pouch (kantong stik) sangat tepat untuk mengatasi permasalahan tersebut. Karena media kantong ajaib tersebut bisa membantu mereka agar bisa mengenal angka dengan benar. Dengan mengguakan media stick pouch peserta didik lebih cenderung menjadi aktif dan merasa tidak jenuh, karena pada hakikatnya dunia mereka adalah dunia anak-anak/dunia bermain. Media ini sangat cocok digunakan dalam pembelajaran mengenal angka dan secara tidak langsung mereka merasa sedang

\footnotetext{
${ }^{5}$ Choiroh, Uchi Nur Uzzlifatul. 2019. Peningkatan Kemampuan Berhitung Siswa Menggunakan Media Stick Pouch Materi Perkalian dan Pembagian Kelas II MI At Taqwa Kraton Pasuruan. Skripsi tidak diterbitkan. Surabaya: PGMI. Fakultas Tarbiyah dan Keguruan, UIN Sunan Ampel. Hal.83

(C) 2021, JoEE, Jurnal of Early Childhood. PGPAUD e-ISSN: 2775-7870
}

bermain hitung-hitungan, tetapi sebenarnya mereka juga sedang belajar. Jadi dengan menggunakan media ini, peserta didik bisa belajar sambil bermain.

Stick pouch (kantong stik) merupakan salah satu media pembelajaran yang berpengaruh pada peningkatan dan pengembangan kemampuan anak dalam mengenal angka-angka. Hal tersebut terlihat dari hasil beberapa penelitian yang menyimpulkan bahwa ada pengaruh signifikan penggunaan media pembelajaran stick pouch (kantong stik) terhadap kemampuan kognitif anak. Salah satu penelitian tersebut adalah oleh Uchi Nur Uzzlifatul Choiroh (2019), yang menunjukkan bahwa dengan menerapkan media pembelajaran stick pouch (kantong stik) dapat meningkatkan kemampuan berhitung siswa Kelas II MI At Taqwa Kraton Pasuruan. 5

Senada dengan hal itu, ada juga penelitian yang dilakukan oleh Arini Sayayona Z (2019), yang menunjukkan bahwa Kegiatan Bermain Stik Angka mampu meningkatkan kemampuan berhitung permulaan pada anak usia 5-6 tahun. ${ }^{6}$

Berdasarkan latar belakang masalah yang diuraikan diatas, maka perlu dilaksanakan penelitian dengan judul "Efektivitas Penggunaan Media Stick Pouch (Kantong Stik) Sebagai Media Pengembangan Kemampuan Kognitif Mengenal Konsep Bilangan 1-10 Anak TK"

\section{Rumusan Masalah}

Untuk memberikan arahan bagi langkah-langkah penelitian selanjutnya maka perlu dirumuskan masalah-masalah khusus penelitian, yakni Bagaimana Efektivitas Penggunaan Media Stick Pouch

\footnotetext{
6 Sapayona Z, Arini. 2019. Pengaruh Kegiatan Bermain Stik Angka Terhadap Kemampuan Berhitung Permulaan Pada Anak Usia 5-6 Tahun. Skripsi tidak diterbitkan. Bandar Lampung: UNILA. Hal.42
} 
Larasati Nur Indah Prawesti dan Mustika Dewi. Efektivitas Penggunaan Media Stick Pouch (Kantong Stik) Sebagai Media Pengembangan Kemampuan Kognitif Mengenal Konsep Bilangan 1-10 Anak $\mathrm{Tk}$

(Kantong Stik) Sebagai Media

Pengembangan Kemampuan Kognitif Mengenal Konsep Bilangan 1-10 Anak TK?

Tujuan Penelitian

Berdasarkan permasalahn diatas, penelitian ini bertujuan untuk mengetahui Efektivitas Penggunaan Media Stick Pouch (Kantong Stik) Sebagai Media Pengembangan Kemampuan Kognitif Mengenal Konsep Bilangan 1-10 Anak TK.

\section{METODE}

Metode penelitian yang digunakan dalam penelitian ini yaitu Studi Literatur. Metode studi literatur adalah serangkaian kegiatan yang berkenaan dengan metode pengumpulan data pustaka, membaca dan mencatat, serta mengelolah bahan penelitian. (Rian, 2018:152-153).

\section{HASIL DAN PEMBAHASAN}

Hasil

Keterlibatan guru, dalam pembaharuan pendidikan, mulai dari perencanaan inovasi pendidikan sampai pada pelaksanaan dan evaluasinya memainkan peran yang sangat besar bagi keberhasilan suatu inovasi pendidikan. Tanpa keterlibatan mereka, maka sangat mungkin mereka tidak perduli dengan inovasi yang ditawarkan, bahkan menolak inovasi yang diperkenalkan kepada mereka tersebut. Hal ini dikarenakan mereka menganggap inovasi yang tidak melibatkan 1. mereka bukanlah miliknya yang harus dilaksanakan, tetapi sebaliknya mereka menganggap akan mengganggu ketenangan dan kelancaran tugas mereka.

Oleh karena itu dalam suatu inovasi pendidikan, gurulah yang utama dan pertama terlibat karena guru mempunyai peran yang luas sebagai pendidik, orang tua, teman, dokter, motivator dan lain sebagainya.

Mendidik berarti pemberian bimbingan pada anak agar potensi yang

dimilikinya berkembang seoptimal mungkin dan dapat meneruskan serta mengembangkan nilai-nilai hidup. Sebab tugas guru disamping menyampaikan ilmu pengetahuan, juga mencakup pembentukan nilai-nilai pada diri murid yang tertuju pada pengembangan seluruh aspek kepribadian murid secara utuh agar tumbuh menjadi manusia dewasa.

Mengajar berarti memberikan pengajaran dalam bentuk penyampaian pengetahuan (kognitif), sikap (afektif) dan ketrampilan (psikomotor) pada diri murid agar dapat menguasai dan mengembangkan ilmu dan teknologi. Guru sebagai pengajar lebih menekankan pada pelaksanaan tugas merencanakan, melaksanakan proses belajar-mengajar dan menilai hasilnya. Untuk melaksanakan tugas ini, guru disamping harus menguasai materi atau bahan yang akan diajarkan, juga dituntut untuk memiliki seperangkat pengetahuan dan ketrampilan teknis mengajar.

Sehubungan dengan tanggung jawab profesional, dalam melaksanakan tugas mengajar ini, guru dituntut untuk selalu mencari gagasan-gagasan baru (inovasi), berusaha menyempurnakan pelaksanaan tugas mengajar, mencobakan bermacammacam metode dalam mengajar dan mengupayakan pembuatan serta penggunaan alat peraga dalam mengajar.

\section{Efektivitas Media Stick Pouch (Kantong Stik) dalam Mengembangkan Kemampuan Kognitif}

Berdasarkan hasil observasi awal terlihat siswa kurang begitu mengenal bilangan yang disampaikan oleh guru. Ketika guru menerangkan materi bilangan, sebagian besar siswa kurang mendengarkan dan memperhatikan materi yang disampaikan oleh guru. Siswa masih terlihat berbicara dan bermain sendiri dengan temannya. Siswa terlihat kurang fokus dan kurang aktif dalam kegiatan 
belajarmengenal bilangan. Mereka terlihat kurang bersemangat, begitu juga ketika guru memberikan tugas kepada anak, mereka cenderung tidak tertarik.

Hal ini berdampak pada masih rendahnya kemampuan mengenal bilangan pada anak. Pada saat anak diberi kegiatan untuk menyebutkan urutan bilangan dari 110, anak masih banyak yang belum bisa mengerjakan. Dari peserta didik yang berjumlah 20 anak, baru 7 anak yang mampu menyebutkan urutan bilangan dengan baik.

Pengambilan dan pengumpulan data dilakukan melalui kajian terhadap pustaka primer yang dihimpun oleh peneliti. Hasil penelitian yang didapatkan adalah terdapat 4 skripsi dan 1 jurnal yang berkaitan dengan media pembelajaran kantong stik daan kemampuan kognitif anak dalam mengenal bilangan permulaan. Data dari sumber primer ini disajikan kembali dengan cara deskriptif kualitatif dan kuantitatif. Hasil penelitian dari skripsi terdahulu yang digunakan sebagai bahan analisis data dihimpun dalam table di bawah ini:

\section{Tabel 4.1}

Kode Data A1

\section{Skripsi Uchi Nur Uzzlifatul Choiroh (2019)}

\begin{tabular}{|c|c|}
\hline \multicolumn{2}{|r|}{ Kode Data A1 } \\
\hline Penulis & Uchi Nur Uzzlifatul Choiroh (2019) \\
\hline $\begin{array}{l}\text { Judul } \\
\text { Skripsi }\end{array}$ & $\begin{array}{l}\text { Peningkatan Kemampuan Berhitung } \\
\text { Siswa Menggunakan Media Stick } \\
\text { Pouch Materi Perkalian dan } \\
\text { Pembagian Kelas II MI At Taqwa } \\
\text { Kraton Pasuruan }\end{array}$ \\
\hline Tujuan & $\begin{array}{l}\text { Untuk meningkatkan kemampuan } \\
\text { berhitung siswa pada materi } \\
\text { perkalian dan pembagian pada } \\
\text { bilangan cacah di kelas II MI At } \\
\text { Taqwa Kraton Pasuruan telah } \\
\text { dilaksanakan dengan baik }\end{array}$ \\
\hline $\begin{array}{l}\text { Metode } \\
\text { Penelitian }\end{array}$ & Penelitian Tindakan Kelas (PTK) \\
\hline $\begin{array}{l}\text { Teknik } \\
\text { Pengump } \\
\text { ulan Data }\end{array}$ & $\begin{array}{l}\text { Tes, observasi, wawancara, dan } \\
\text { dokumentasi }\end{array}$ \\
\hline $\begin{array}{l}\text { Hasil } \\
\text { Penelitian }\end{array}$ & $\begin{array}{l}\text { Pada kegiatan pra siklus sebelum } \\
\text { menerapkan metode bermain }\end{array}$ \\
\hline
\end{tabular}

(C) 2021, JoEE, Jurnal of Early Childhood. PGPAUD e-ISSN: 2775-7870

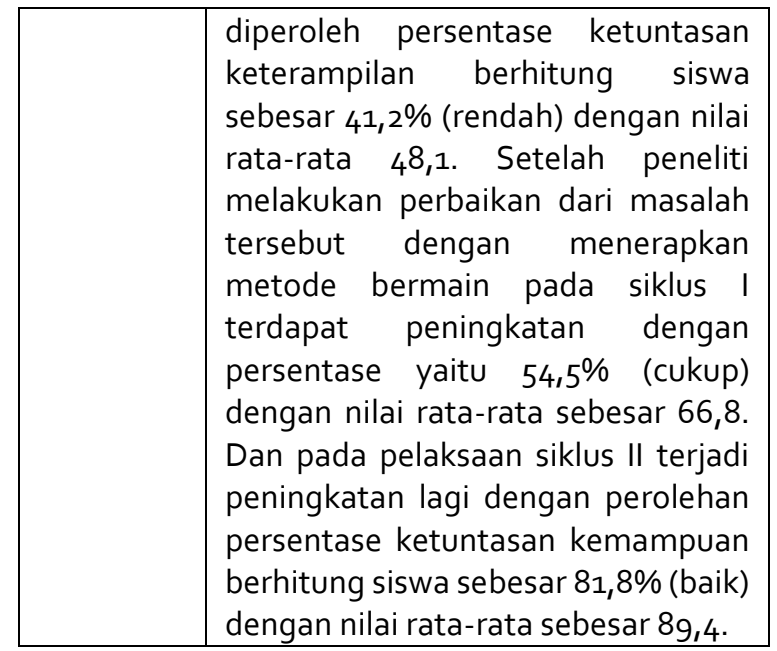

Dari hasil penelitian di atas, didapatkan hasil bahwa penelitian ini menggunakan model Kurd Lewin yang terdiri dari empat langkah yaitu: 1. Perencanaan, 2. Tindakan, 3. Observasi, 4. Refleksi. Subyek penelitiannya adalah siswa kelas II MI At Taqwa Kraton Pasuruan dengan jumlah 11 siswa, terdiri dari 4 perempuan dan 8 laki-laki. Penelitian dilakukan dengan 2 siklus. Teknik pengumpulan datanya melalui tes, observasi, wawancara, dan dokumentasi.

Penerapan metode bermain ini bertujuan untuk meningkatkan kemampuan berhitung siswa pada materi perkalian dan pembagian pada bilangan cacah di kelas II MI At Taqwa Kraton Pasuruan telah dilaksanakan dengan baik. Hal tersebut dapat dibuktikan dengan data hasil observasi aktivitas guru dan siswa yang diperoleh peneliti. Pada siklus I diperoleh hasil dari observasi aktivitas guru yaitu sebesar 83 (tinggi), kemudian dilakukan lagi perbaikan dari siklus I yaitu pada siklus II hingga memperoleh peningkatan sebesar 95 (sangat tinggi). Perolehan hasil observasi aktivitas siswa pada siklus I memperoleh angka 82 (tinggi) dan mengalami peningkatan pada siklus II sebesar 90 (sangat tinggi).

Dari data table di atas, dapat dilihat bahwa pada kegiatan pra siklus sebelum menerapkan metode bermain diperoleh persentase ketuntasan keterampilan berhitung siswa sebesar 41,2\% (rendah) 
Larasati Nur Indah Prawesti dan Mustika Dewi. Efektivitas Penggunaan Media Stick Pouch (Kantong Stik) Sebagai Media Pengembangan Kemampuan Kognitif Mengenal Konsep Bilangan 1-10 Anak $\mathrm{Tk}$

dengan nilai rata-rata 48,1. Setelah peneliti melakukan perbaikan dari masalah tersebut dengan menerapkan metode bermain pada siklus I terdapat peningkatan dengan persentase yaitu $54,5 \%$ (cukup) dengan nilai rata-rata sebesar 66,8. Dan pada pelaksaan siklus II terjadi peningkatan lagi dengan perolehan persentase ketuntasan kemampuan berhitung siswa sebesar $81,8 \%$ (baik) dengan nilai rata-rata sebesar 89,4 .

$\mathrm{Hal}$ ini menunjukan bahwa terdapat peningkatan keterampilan berhitung siswa materi perkalian dan pembagian pada bilangan cacah di kelas II MI At Taqwa Kraton Pasuruan. Peningkatan kemampuan berhitung pada materi perkalian dan pembagian pada bilangan cacah ini dapat dilihat dari ketuntasan belajar siswa pada setiap siklusnya.

\section{Tabel 4.2 Kode Data A2 \\ Skripsi Eki Trisnawati (2018)}

\begin{tabular}{|c|c|}
\hline \multicolumn{2}{|r|}{ Kode Data A2 } \\
\hline Penulis & Eki Trisnawati (2018) \\
\hline $\begin{array}{l}\text { Judul } \\
\text { Skripsi }\end{array}$ & 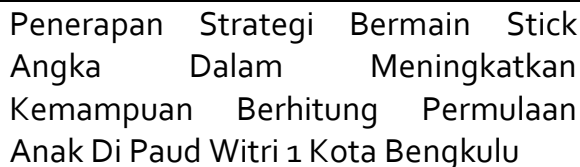 \\
\hline Tujuan & $\begin{array}{l}\text { Untuk meningkatkan kemampuan } \\
\text { berhitung permulaan anak }\end{array}$ \\
\hline $\begin{array}{l}\text { Metode } \\
\text { Penelitian }\end{array}$ & Penelitian Tindakan Kelas (PTK) \\
\hline $\begin{array}{l}\text { Teknik } \\
\text { Pengump } \\
\text { ulan Data }\end{array}$ & Tes, observasi dan dokumentasi \\
\hline $\begin{array}{l}\text { Hasil } \\
\text { Penelitian }\end{array}$ & $\begin{array}{l}\text { Kemampuan berhitung permulaan anak } \\
\text { belum optimal, dapat diketahui } \\
\text { kepekaan anak anak mencapai } 50,53 \% \text {, } \\
\text { pemahaman anak mencapai } 53,01 \% \text {, } \\
\text { dan komunikasi anak } 51,22 \% \text {. Hasil rata- } \\
\text { rata kelas yang dicapai } 51,57 \% \text {. Hasil } \\
\text { tersebut belum mencapai batas kriteria } \\
\text { yang akan dicapai peneliti sebesar } 75 \% \text {. }\end{array}$ \\
\hline
\end{tabular}

Dari hasil penelitian di atas, berdasarkan hasil penelitian yang dilakukan peneliti terhadap penerapan permainan stick angka dalam meningkatkan kemampuan berhitung permulaan anak pada kelompok B Witri 1 Kota Bengkulu diperoleh data bahwa dapat peneliti simpulkan bahwa kemampuan berhitung permulaan anak belum optimal, dapat diketahui kepekaan anak anak mencapai 50,53\%, pemahaman anak mencapai $53,01 \%$, dan komunikasi anak 51,22\%. Hasil rata-rata kelas yang dicapai $51,57 \%$. Hasil tersebut belum mencapai batas kriteria yang akan dicapai peneliti sebesar $75 \%$.

Hasil penelitian menunjukkan, melalui permainan stick angka secara keseluruhan terbukti efektif dalam meningkatkan prestasi kemampuan berhitung permulaan anak. Hal Ini dapat dilihat melalui tindakan pra siklus, siklus I dan siklus II yang terjadi peningkatan kemampuan berhitung permulaan anak yang signifikan. Selanjutnya melalui pendekatan permainan stick angka anak dapat lebih aktif dan memberikan pengetahuan dan pengalaman baru dalam pembelajaran.

Berdasarkan hal tersebut, dapat ditarik kesimpulan didapatkan hasil bahwa penelitian melalui permainan stick angka secara keseluruhan terbukti efektif dalam meningkatkan prestasi kemampuan berhitung permulaan anak. Ini dapat dilihat melalui tindakan pra siklus, siklus I dan siklus II yang terjadi peningkatan kemampuan berhitung permulaan anak yang signifikan.

\section{Table 4.3 Kode Data $\mathrm{A}_{3}$}

Skripsi Yenis Astina Mulyaningsih (2016)

\begin{tabular}{|l|lr|}
\hline \multicolumn{3}{|c|}{ Kode Data A3 } \\
\hline Penulis & \multicolumn{3}{|c|}{ Yenis Astina Mulyaningsih (2016) } \\
\hline Judul & Bermain Stick & Angka Untuk \\
Skripsi & Meningkatkan & Kemampuan \\
& Berhitung Permulaan Pada Anak \\
& Kelompok B Di TK Desa Wonolopo \\
& $\begin{array}{l}\text { Tasikmadu Karanganyar Tahun } \\
\text { Ajaran 2015-2016 }\end{array}$ \\
\hline Tujuan & Meningkatkan & \\
& berhitung permulaan \\
\hline Metode & Penelitian Tindakan Kelas (PTK) \\
Penelitian & \multicolumn{2}{l}{} \\
\hline
\end{tabular}




\begin{tabular}{|l|l|}
\hline $\begin{array}{l}\text { Teknik } \\
\text { Pengumpul } \\
\text { an Data }\end{array}$ & Tes, observasi dan dokumentasi \\
\hline $\begin{array}{l}\text { Hasil } \\
\text { Penelitian }\end{array}$ & $\begin{array}{l}\text { Hasil persentase dari kemampuan } \\
\text { berhitung permulaan dari sebelum } \\
\text { diberi tindakan sampai sampai } \\
\text { siklus II yakni prasiklus 47,25\%, } \\
\text { siklus I } 57,75 \% \text { dan siklus II } 86,37 \%\end{array}$ \\
\hline
\end{tabular}

Dari hasil penelitian di atas, didapat keterangan bahwa Perbedaan penelitian ini dengan penelitian penulis adalah terletak pada kemampuan kognitif yang berbeda, yakni kemampuan berhitung permulaan.

Dalam penelitian ini, jenis penelitian yang digunakan Penelitian Tindakan Kelas (PTK) dengan prosedur kerja dua siklus, terdiri dari empat tahap. Subjek penelitian ini adalah guru dan anak kelompok B di TK Desa Wonolopo Tasikmadu Karanganyar.

Hasil penelitian ini menunjukkan bermain stick angka mampu meningkatkan kemampuan berhitung permulaan. Hasil persentase dari kemampuan berhitung permulaan dari sebelum diberi tindakan sampai sampai siklus II yakni prasiklus $47,25 \%$, siklus I $57,75 \%$ dan siklus II $86,37 \%$.

\section{Table 4.4 \\ Kode Data $\mathrm{A}_{4}$}

Skripsi Supartini (2012)

\begin{tabular}{|c|c|}
\hline \multicolumn{2}{|r|}{ Kode Data $\mathrm{A}_{4}$} \\
\hline Penulis & Supartini (2012) \\
\hline $\begin{array}{l}\text { Judul } \\
\text { Skripsi }\end{array}$ & $\begin{array}{l}\text { Meningkatkan Kemampuan } \\
\text { Berhitung Pengurangan Dengan } \\
\text { Teknik Meminjam Melalui } \\
\text { Penerapan Media Kantong Nilai } \\
\text { Pada Siswa Kelas II SDN Majenang II } \\
\text { Kecamatan Sukodono Kabupaten } \\
\text { Sragen Tahun Pelajaran 2011/2012 }\end{array}$ \\
\hline Tujuan & $\begin{array}{l}\text { Untuk membuktikan bahwa } \\
\text { menggunakan media kantong nilai } \\
\text { dapat meningkatkan kemampuan } \\
\text { berhitung pengurangan dengan } \\
\text { teknik meminjam pada mata } \\
\text { pelajaran Matematika }\end{array}$ \\
\hline $\begin{array}{l}\text { Metode } \\
\text { Penelitian }\end{array}$ & Penelitian Tindakan Kelas (PTK) \\
\hline $\begin{array}{l}\text { Teknik } \\
\text { Pengump } \\
\text { ulan Data }\end{array}$ & Tes, observasi dan dokumentasi \\
\hline $\begin{array}{l}\text { Hasil } \\
\text { Penelitian }\end{array}$ & $\begin{array}{lrr}\text { Terjadi peningkatan } & \text { kualitas } \\
\text { pembelajaran } & \text { terlihat } & \text { dari }\end{array}$ \\
\hline
\end{tabular}

(C) 2021, JoEE, Jurnal of Early Childhood. PGPAUD e-ISSN: 2775-7870

\begin{tabular}{|c|}
\hline $\begin{array}{l}\text { keberhasilan dan kegagalan beserta } \\
\text { data: sebelum diadakan perbaikan } \\
\text { siswa yang mendapat nilai } 70 \text { ke atas } \\
\text { hanya } 3 \text { anak }(15 \%) \text {. Setelah } \\
\text { pelaksanaan tindakan pada siklus I } \\
\text { sudah ada peningkatan yaitu } 12 \text { anak } \\
(60 \%) \text {, setelah siklus II menunjukkan } \\
\text { kemajuan. Dari } 20 \text { anak yang } \\
\text { mendapat nilai di atas } 70 \text { sebanyak } \\
18 \text { anak }(90 \%)\end{array}$ \\
\hline
\end{tabular}

Dari hasil penelitian di atas, didapatkan informasi bahwa Perbedaan penelitian ini dengan penelitian penulis adalah terletak pada materi pelajaran yang berbeda, yakni media kantong nilai, dan kemampuan kogitifnya tidak lagi pada ranah mengenal angka, tetapi sudah berhitung.

Table di atas menunjukkan bahwa penelitian ini bertujuan untuk membuktikan bahwa menggunakan media kantong nilai dapat meningkatkan kemampuan berhitung pengurangan dengan teknik meminjam pada mata pelajaran Matematika di Kelas II SDN Majenang 2 Kecamatan Sukodono, Kabupaten Sragen.

Penelitian ini merupakan Penelitian Tindakan Kelas (PTK) dengan menggunakan langkah-langkah menyusun rencana, pelaksanaan, pengumpulan data dan mengadakan refleksi. Subyek dalam penelitian ini adalah siswa kelas II SDN Majenang 2 yang berjumlah 20 siswa. Teknik pengumpulan data dengan wawancara, observasi langsung dan hasil nilai test.

Analisis data diperoleh melalui hasil tes formatik. Hasil PTK adalah bahwa media kantong nilai dapat meningkatkan kemampuan berhitung pada siswa kelas II SDN majenang 2 . Terjadi peningkatan kualitas pembelajaran terlihat dari keberhasilan dan kegagalan beserta data: sebelum diadakan perbaikan siswa yang mendapat nilai 70 ke atas hanya 3 anak (15\%). Setelah pelaksanaan tindakan pada siklus I sudah ada peningkatan yaitu 12 anak $(60 \%)$, setelah siklus II menunjukkan 
Larasati Nur Indah Prawesti dan Mustika Dewi. Efektivitas Penggunaan Media Stick Pouch (Kantong Stik) Sebagai Media Pengembangan Kemampuan Kognitif Mengenal Konsep Bilangan 1-10 Anak $\mathrm{Tk}$

kemajuan. Dari 20 anak yang mendapat nilai di atas 70 sebanyak 18 anak (90\%).

\section{Table 4.5 \\ Kode Data A5}

Jurnal Sumiyati dan Daryati (2017)

\begin{tabular}{|c|c|}
\hline \multicolumn{2}{|r|}{ Kode Data $A_{5}$} \\
\hline Penulis & Sumiyati dan Daryati (2017) \\
\hline $\begin{array}{l}\text { Judul } \\
\text { Skripsi }\end{array}$ & $\begin{array}{l}\text { Upaya Meningkatkan Kemampuan Anak } \\
\text { Belajar Berhitung Permulaan Melalui } \\
\text { Media Kantong Stik di TK Bhakti } \\
\text { Masyarakat Pagerharjo Pati }\end{array}$ \\
\hline Tujuan & $\begin{array}{l}\text { Untuk mengetahui kemampuan belajar } \\
\text { berhitung permulaan pada anak }\end{array}$ \\
\hline $\begin{array}{l}\text { Metode } \\
\text { Penelitian }\end{array}$ & Penelitian Tindakan Kelas (PTK) \\
\hline $\begin{array}{l}\text { Teknik } \\
\text { Pengump } \\
\text { ulan Data }\end{array}$ & Tes, observasi dan dokumentasi \\
\hline $\begin{array}{l}\text { Hasil } \\
\text { Penelitian }\end{array}$ & $\begin{array}{l}\text { Kemampuan berhitung permulaan yang } \\
\text { termasuk kategori Berkembang Sangat } \\
\text { Baik (BSB) dan Berkembang Sesuai } \\
\text { Harapan (BSH) hanya sebesar } 35 \% \text { dan } \\
\text { setelah dilakukan tindakan dengan } \\
\text { media kantong stik kemampuan } \\
\text { berhitung permulaan anak naik menjadi } \\
95 \% \text {. }\end{array}$ \\
\hline
\end{tabular}

Dari hasil penelitian di atas, dapat dilihat bahwa tujuan penelitian ini adalah (1) Untuk mengetahui kemampuan belajar berhitung permulaan pada anak kelompok B di TK Bhakti Masyarakat Pagerharjo Wedarijaksa Pati, dan (2) Untuk mengetahui apakah penggunaan media kantong stik dapat meningkatkan kemampuan belajar berhitung permulaan pada anak kelompok B di TK Bhakti Masyarakat Pagerharjo Wedarijaksa Pati. Jenis penelitian ini adalah Clasroom Action Reseach dengan menggunakan dua siklus di mana setiap siklusnya meliputi empat komponen yaitu menyusun rencana tindakan (planning), pelaksanaan tindakan (acting), dan pengamatan (observing), serta refleksi (reflecting).

Kesimpulan penelitian adalah kemampuan belajar berhitung permulaan pada anak kelompok B di TK Bhakti Masyarakat Pagerharjo Wedarijaksa Pati sebelum dilaksanakan penelitian masih rendah. Hal ini ditunjukkan dari kemampuan berhitung permulaan yang termasuk kategori Berkembang Sangat Baik (BSB) dan Berkembang Sesuai Harapan (BSH) hanya sebesar 35\% dan setelah dilakukan tindakan dengan media kantong stik kemampuan berhitung permulaan anak naik menjadi $95 \%$.

Berdasarkan table di atas menunjukkan bahwa adanya peningkatan kemampuan kognitif anak baik dalam mengenal angka maupun dalam kegiatan berhitung permulaan melalui media pembelajaran stik angka dan kantong stik. Hal ini dapat dibuktikan dengan terjadinya peningkatan skor yang cukup signifikan dari masing-masing penelitian tersebut.

Hal ini dapat disimpulkan bahwa media kantong stik dapat meningkatkan kemampuan kognitif siswa. Adapun hasil analisis keseluruhan data primer dapat dirangkum dalam table berikut ini:

\section{Tabel 4.7}

Persentase Peningkatan Kemampuan

Kognitif Anak Dengan Media Kantong

Stik

\begin{tabular}{|c|c|c|c|c|c|}
\hline \multirow[b]{2}{*}{ No } & \multirow{2}{*}{$\begin{array}{l}\text { Kode } \\
\text { Data }\end{array}$} & \multicolumn{3}{|c|}{ Persentase } & \multirow[b]{2}{*}{$\begin{array}{l}\text { Rata- } \\
\text { rata }\end{array}$} \\
\hline & & Awal & Siklus I & Siklus II & \\
\hline 1 & $\mathrm{~A}_{1}$ & $41.2 \%$ & $54.5 \%$ & $81.8 \%$ & $59.17 \%$ \\
\hline 2 & $\mathrm{~A}_{2}$ & $50 \%$ & $65 \%$ & $78 \%$ & $64.3 \%$ \\
\hline 3 & $A_{3}$ & $47.25 \%$ & $57.75 \%$ & $86.37 \%$ & $63.78 \%$ \\
\hline 4 & $\mathrm{~A}_{4}$ & $15 \%$ & $60 \%$ & $90 \%$ & $55 \%$ \\
\hline 5 & $A_{5}$ & $35 \%$ & $65 \%$ & $95 \%$ & $65 \%$ \\
\hline \multicolumn{2}{|c|}{ Rata-rata } & $37.69 \%$ & $60.45 \%$ & $86.23 \%$ & $61.46 \%$ \\
\hline
\end{tabular}

Berdasarkan tabel di atas, dari kelima hasil penelitian sumber primer yang digunakan, dapat dilihat bahwa terjadi peningkatan yang cukup signifikan terhadap kemampuan kognitif anak usia dini dalam mengenal bilangan 1-10 dengan menggunakan media pembelajaran kantong stik. Selisih persentase terkecil ada pada kode $A_{4}$, yakni dengan kenaikan ratarata sebesar $55 \%$., dan selisih persentase 
terbesar ada pada kode data $\mathrm{A}_{5}$, yakni dengan kenaikan rata-rata sebesar $65 \%$

Adapun mengacu pada tabel, rinciannya adalah kode data $\mathrm{A} 1$ dari $41.2 \%$ meningkat menjadi $81,8 \%$ sehingga peningkatan yang terjadi diperoleh angka sebesar $59.17 \%$. Kode data A2 meningkat dari $50 \%$ naik manjadi $78 \%$ sehingga peningkatan yang diperoleh sebesar $64.3 \%$. Kode data $\mathrm{A}_{3}$ meningkat dari $47.25 \%$ menjadi $86.37 \%$ sehingga didapat peningkatan sebesar $63.78 \%$.

Dari data tersebut diperoleh persentase nilai rata-rata penggunaan media stik angka dengan kantong stik untuk meningkatkan kemampuan kognitif anak dalam mengenal bilangan meningkatkan secara signifikan yaitu dari $37.69 \%$ sebelum menggunakan media tersebut naik menjadi $60.45 \%$ setelah menggunakan media stik angka dengan kantong stik, dan naik lagi pada siklus berikutnya sebesar $86.23 \%$, sehingga terjadi peningkatan rata-rata sebesar 61.46\%. Berdasarkan hasil ini, dapat disimpulkan bahwa media kantong stik sangat efektif dalam meningkatkan kemampuan kognitif anak usia dini dalam mengenal bilangan 1-10.

\section{Pembahasan}

Anak merupakan individu yang unik dan memiliki kekhasan tersendiri. Kajian tentang anak selalu menarik sehingga memunculkan berbagai pandangan tentang arti sebenarnya hakikat seorang anak. Guru anak usia dini sebagai pelaku pendidikan yang secara langsung berhadapan dengan anak sangat penting memahaminya sesuai dengan tugas perkembangan anak pada setiap tingkat usia tertentu.

Ketidakpahaman tentang hal tersebut akan membuat guru terjebak dalam kegiatan rutin yang tidak mengacu kepada kebutuhan anak secara individual maupun kelompok, bahkan akan menciptakan pembelajaran yang membosankan bagi anak. Hal tersebut disebabkan karena kegiatan dari hari ke hari tetap sama tanpa kegiatan yang menantang atau menarik.

Banyak sekali peranan guru yang harus dilakukan dalam melaksanakan tugas di sekolah. Namun secara profesional, seorang guru berdasarkan tuntutan kompetensinya meliputi tugas mendidik, mengajar dan melatih.

Kunci utama yang harus dipegang guru adalah bahwa setiap proses atau produk inovatif yang dilakukan dan dihasilkannya harus mengacu kepada kepentingan siswa.

"Ujung tombak keberhasilan pendidikan di sekolah adalah guru oleh karena itu guru diharapkan mampu menjadi seorang yang inovatif guna menemukan strategi atau metode yang efektif untuk mendidik. Inovasi yang dilakukan guru pada intinya berada dalam tatanan pembelajaran yang dilakukan di kelas".7

Pembelajaran pada Anak Usia Dini pada hakikatnya adalah pengembangan kurikulum secara konkret berupa seperangkat rencana yang berisi sejumlah pengalaman belajar melalui bermain yang diberikan kepada anak usia dini berdasarkan potensi dan tugas perkembangan yang harus dikuasainya dalam rangka pencapaian kompetensi yang di miliki oleh anak.

Pendidikan pada dasarnya tidak melulu menghabiskan waktu di bangku sekolah formal. Akan tetapi, pendidikan bisa pula di peroleh dan diraih di dalam sebuah bermain sambil belajar. Rata-rata anak selalu menyukai sebuah permainan. Dalam hal ini sebenarnya permainan memiliki titik sentral terhadap perkembangan anak karena fungsi permainan bagi anak adalah sebagai alat

\footnotetext{
7 Wawancara dengan lip Saripah, Kepala Sekolah/Pimpinan TK Insan Syazani Kota Cilegon, pada selasa, 6 Oktober 2020 pukul 09.00 WIB (C) 2021, JoEE, Jurnal of Early Childhood. PGPAUD e-ISSN: 2775-7870
} 
Larasati Nur Indah Prawesti dan Mustika Dewi. Efektivitas Penggunaan Media Stick Pouch (Kantong Stik) Sebagai Media Pengembangan Kemampuan Kognitif Mengenal Konsep Bilangan 1-10 Anak $\mathrm{Tk}$

untuk merangsang pertumbuhan, perkembangan maupun kecerdasan dasar seorang anak.

Metode bermain sambil belajar dengan pusat kegiatan (sentra) dapat mengarahkan anak untuk menemukan potensi dan kecerdasan yang dimiliki. Metode tersebut cukup efektif dalam membantu anak usia prasekolah dalam belajar. Selain itu, metode yang di gunakan juga mampu mengembangkan aspek pada bidang bahasa, pikir, visual, kinestetik, musik, intra personal, dan inter personal pada anak.

"Bermain adalah dunia anak karena bermain merupakan aktivitas yang sangat menyenangkan bagi mereka. Dengan bermain anak dapat belajar mencapai perkembangan baik perkembangan fisik, emosi, intelektualitas maupun jiwa sosial nya. Saat bermain dapat dilihat perekmbangan-perkembangan tersebut, bagaimana anak meningkatkan kemampuan fisiknya, bagaimana perasaannya saat menang atau kalah dalam permainan, bagaimana kemampuan intelektualnya dalam memanfaatkan benda-benda sebagai mainan, bagaimana pula kematangan sosialnya dalam bermain bersama". 8

Konsep bermain sambil belajar atau sebaliknya, mencerminkan bahwa dunia anak adalah dunia bermain, sehingga seluruh proses pembelajaran harus 100\% dalam suasana yang menyenangkan. Dengan sistem pembelajaran tersebut maka proses mengajar anak akan mencapai hasil optimal. 9

"Bermain membutuhkan sarana atau alat yang menunjang agar tujuan permainan

\footnotetext{
${ }^{8}$ Wawancara dengan lip Saripah, Ibid, pada selasa, 6 Oktober 2020 pukul og.00 WIB

${ }_{9}$ Mursid. (2015). Ibid. Hal 150

${ }^{10}$ Wawancara dengan Iffat Shanika Aska, Guru TK Insan Syazani Kota Cilegon. Ibid. pada selasa, 6 Oktober 2020 pukul 12.00 WIB

(C) 2021, JoEE, Jurnal of Early Childhood. PGPAUD e-ISSN: 2775-7870
}

dapat tercapai. Sarana atau alat tersebut harus bisa membangkitkan ketertarikan dan semangat dengan tujuan agar anak mau secara terbuka menggunakannya. Penggunaannya juga harus mudah. Bermain dengan sarana yang tepat akan memberikan pengalaman bagi anak karena anak akan terlibat langsung dengan permainan tersebut" ${ }^{10}$

Kegiatan pembelajaran pada dasarnya merupakan proses komunikasi. Dalam proses komunikasi tersebut, guru bertindak sebagai komunikator (communicator) yng bertugas menyampikan pesan pembelajaran (messags) kepada penerima pesan (communicant), yaitu anak. Agar pesan-pesan pembelajaran yang disampaikan guru dapat diterima dengan baik oleh anak, maka dalam proses komunikasi pembelajaran tersebut diperluan wahana penyalur pesan yang disebut media pembelajaran ${ }^{11}$.

Peran media dalam komunikasi pembelajaran bagi anak usia dini semakin penting artinya mengingat perkembangan anak pada saat itu berada pada masa konkret. Oleh karena itu, salah satu prinsip pembelajaran di TK adalah kekonkretan, artinya bahwa anak doharapkan dapat mempelajari sesuatu secara nyata. Dengan demikian, pembelajaran di TK harus menggunakan sesuatu yang memungkinkan anak dapat belajar secara konkret. Prinsip kekonkretan ini mengisyaratkan perlunya digunakan media sebagai saluran penyampai pesan dari guru kepada anak didik agar pesan/informasi tersebut dapat diterima atau dicerap anak dengan baik. Dengan begitu, diharapkan terjadi perubahan-perubahan perilaku

\footnotetext{
${ }^{11}$ Zaman, Badru dkk. 2012. Media dan Sumber Belajar TK. Universitas Terbuka: Tangerang Selatan. Hal. 4.3
} 
berupa kemampuan-kemampuan dalam hal pengetahuan, sikap, dan keterampilan.

Media kantong stik ini juga masuk kepada metode demonstrasi, karena guru terlebih dahulu memperagakan bagaimana cara memainkannya. Metode demontrasi adalah suatu strategi pengembangan dengan cara memberikan pengalaman belajar melalui perbuatan melihat dan mendengarkan yang diikuti dengan meniru pekerjaan yang di demonstrasikan. Metode demonstrasi dapat juga dikatakan sebagai setuatu metode untuk memperagaikan serangkaian tindakan berupa gerakan yang menggambarkan suatu cara kerja atau urutan proses sebuah peristiwa atau kejadian. Biasanya metode demonstrasi ini dipakai untuk membutktikan sesuatu atau gerakan untuk di contoh.

"Di dalam kegiatan anak usia dini, banyak jenis kegiatan yang tidak cukup dimengerti oleh anak apabila hanya disampaikan dengan penjelasan verbal, tetapi perlu penjelasan dengan cara memperlihatkan suatu cara kerja berupa tindakan/gerakan. Misalnya, dalam kegiatan keterampilan yang berupa melipat, menggunting, membentuk, dalam kegiatan jasmani, seperti cara melempar atau menangkap bola, cara memanjat, meniti papan titian, atau kegiatan sains seperti membuktikan pencampuran warna, atau dalam kegiatan matematika misalnya mengenal jumlah bilangan dengan menggunakan potongan lidi, serta dalam kegiatan seni, misalnya cara menari, dan cara memainkan alat music". ${ }^{12}$

Dalam penguasaan keterampilan, anak lebih muda mempelajarinya dalam cara menirukan seperti apa yang dilakukan oleh guru. Dalam hal ini, guru menunjukkan, mengajarkan dan menjelaskan apa yang sedang di lakukan (showing, doing, telling). Tiga macam perbuatan guru ini merupakan

\footnotetext{
${ }^{12}$ Wawancara dengan lip Saripah. Ibid
}

komponen yang utama dalam metode demonstrasi.

Demonstrasi dapat dilakukan sebagai improfisasi maupun di rancang terlebih dahulu. Keduanya sangat efektif dalam kegiatan pembelajaran pada anak usia dini. Metode demonstrasi yang di pandukan dengan metode penemuan, memungkinkan guru membimbing anak menemukan hal-hal baru berdasarkan praduga atau hipotesis yang di susun oleh anak dari hasil pembuktian itu anak akan dapat menarik kesimpulan yang berlaku secara umum. Anak-anak membuat praduga dengan menerapkan pengetahuan yang telah di milikinya dan mengujinya pada kegiatan demonstrasi tersebut.

Melalui kegiatan demonstrasi, guru dapat meningkatkan pemahaman anak melalui penglihatan dan pendengaran. Anak diminta untuk memperhatikan dan mendengarkan baik-baik semua keterangan guru sehingga dia lebih paham tentang cara mengerjakan sesuatu. Dengan demikian, selanjutnya akan meniru bagaimana cara nya melakukan hal tersebut seperti yang di contohkan oleh guru. ${ }^{13}$

Kemampuan mengenal angka pada anak sudah terlihat dengan menggunakan media kantong stik angka. Pada prosesnya, kemampuan mengenal angka pada anak mulai terlihat peningkatan dan antusiasnya dalam mengikuti kegiatan pembelajaran setelah menggunakan media tersebut. Begitupun pada anak sudah terlihat antusias dalam mengikuti kegiatan serta sudah mulai terlihat peningkatannya.

"Salah satu upaya yang harus
dilakukan guru adalah dengan
menggunakan media (alat peraga) yang lebih kreatif dan inovatif. Pemanfaatan media yang lebih kreatif diharapkan dapat menarik perhatian anak didik, sehingga

\footnotetext{
${ }^{13}$ Winda, Lilis, Azizah. (2014). Metode

Pengembangan Prilaku, dan Kemampuan Dasar Anak Usia Dini. Universitas Terbuka: Jakarta. Hal. 9.3
} 
Larasati Nur Indah Prawesti dan Mustika Dewi. Efektivitas Penggunaan Media Stick Pouch (Kantong Stik) Sebagai Media Pengembangan Kemampuan Kognitif Mengenal Konsep Bilangan 1-10 Anak $\mathrm{Tk}$

anak lebih termotivasi dan bersemangat dalam melaksanakan pembelajaran. Di samping itu kegiatan belajar mengajar juga dapat dikembangkan. Kegiatan belajar mengajar tidak hanya berpusat pada guru saja, anak didik juga perlu dilibatkan dan diaktifkan". ${ }^{14}$

Permainan kantong stik angka adalah suatu bentuk media pembelajaran berbasis permainan untuk menyampaikan suatu materi pembelajaran pada anak usia dini. Penggunaan permainan kantong stik angka diharapkan lebih mudah untuk membantu anak memahami konsep berhitung agar lebih termotivasi dalam belajar berhitung permulaan. Media permainan kantong stik angka yang akan digunakan dalam penelitian adalah permainan yang terbuat dari tongkat, batang, atau potongan kayu. Sedangkan angka merupakan suatu symbol untuk hitungan dengan symbol pokok yaitu $0,1,2,3,4,5,6,7,8$, dan 9. ${ }^{15}$ (Ma'rifah, 2014, hlm. 20).

Sejalan dengan hasil penelitian dari beberapa sumber primer yang peneliti gunakan di atas, media kantong stick angka merupakan salah satu upaya untuk mengembangkan kemampuan kognitif anak dalam mengenal bilangan. Media kantong stick angka dapat dilakukan melalui kegiatan permainan, menyebutkan urutan bilangan dan mengenal lambang bilangan, menghubungkan angka dengan tulisannya.

Hal ini dapat dilihat dari persentase nilai rata-rata penggunaan media stik angka dengan kantong stik untuk meningkatkan kemampuan kognitif anak dalam mengenal bilangan meningkatkan secara signifikan yaitu dari $60.45 \%$ sebelum menggunakan media tersebut naik menjadi

\footnotetext{
14 Wawancara dengan Lufi Lisnawati, Guru TK Insan Syazani Kota Cilegon, pada Rabu, 7 Oktober 2020 Pukul 11.30 WIB
}

$86.23 \%$ setelah menggunakan media stik angka dengan kantong stik, sehingga terjadi peningkatan sebesar $25.83 \%$. Berdasarkan hasil ini, dapat disimpulkan bahwa media kantong stik sangat efektif dalam meningkatkan kemampuan kognitif anak usia dini dalam mengenal bilangan 110 dalam suasana pembelajaran yang menarik, aktif dan menyenangkan.

\section{PENUTUP}

\section{Simpulan}

Hasil penelitian dan pembahasan, berdasarkan dari berbagai sumber yang berhasil dihimpun oleh peneliti, dapat dilihat bahwa ada pengaruh kegiatan belajar dengan media stick pouch (kantong stik) terhadap kemampuan mengenal angka untuk anak usia dini. Hal ini dapat dilihat dari persentase nilai rata-rata penggunaan media stik angka dengan kantong stik untuk meningkatkan kemampuan kognitif anak dalam mengenal bilangan meningkatkan secara signifikan, dari $37.69 \%$ sebelum menggunakan media tersebut naik menjadi $60.45 \%$ setelah menggunakan media stik angka dengan kantong stik, dan naik lagi pada siklus berikutnya sebesar $86.23 \%$, sehingga terjadi peningkatan rata-rata sebesar 61.46\%. Berdasarkan hasil ini, dapat disimpulkan bahwa media kantong stik sangat efektif dalam meningkatkan kemampuan kognitif anak usia dini dalam mengenal bilangan 1-10 dalam suasana pembelajaran yang menarik, aktif dan menyenangkan.

\section{Saran}

Berdasarkan penelitian yang telah dilakukan, penggunaan media stick pouch (kantong stik) mampu untuk meningkatkan

\footnotetext{
15 Ma'rifah. (2014). Upaya Meningkatkan Berhitung Permulaan Menggunakan Permainan Stick Angka Di Kelompok A Tk Dharma Wanita Persatuan Meduran Manyar Gresik. Pengembangan Profesional Keguruan. Gresik: Tidak Diterbitkan.
} 
kemampuan kemampuan kognitif anak usia dini dalam mengenal konsep bilangan 1-10, maka dapat peneliti sarankan kepada pihakpihak yang terkait diantaranya:

\section{Sekolah}

Hendaknya lebih memperhatikan proses belajar mengajar dan meningkatkan kompetensi guru dan potensi siswa sehingga output pembelajaran yang dihasilkan adalah output yang mampu berkompetensi dalam dunia pendidikan, dan juga mendukung proses pembelajaran dengan memberikan fasilitas yang dibutuhkan untuk menciptakan model pembelajaran yang bervariasi dan inovatif.

\section{Kepala Sekolah}

Penelitian ini diharapkan dapat membuka wawasan bagi Kepala Sekolah untuk meningkatkan kemampuan dan kompetensi guru, sehingga guru bisa lebih kreatif dan inovatif dalam menggunakan media pembelajaran yang tepat dan efektif dalam proses pembelajaran, agar bisa menyinergikan kegiatan belajar melaui kegiatan bermain karena pada dasarnya anak usia dini belajar melalui bermain.

\section{Guru}

Guru diharapkan dapat lebih inovatif dan kreatif dalam memberikan permainan yang bermakna bagi anak, memilih alat permainan yang menyenangkan, serta memberikan fasilitas yang lengkap agar anak tertarik pada pembelajaran khususnya dalam pengembangan kemampuan kognitif mengenal bilangan 1-10 anak usia dini. Salah satu kegiatan yang dapat digunakan dalam mengembangkan kemampuan mengenal bilangan pada anak yaitu melalui kegiatan bermain stick pouch (kantong stik).

\section{Bagi Peneliti Selanjutnya}

Karya ilmiah ini bisa dijadikan sebagai referensi dalam penelitiannya yang membahas tentang peningkatan kemampuan kemampuan kognitif mengenal bilangan 1-10 anak usia dini melalui metode bermain untuk menggunakan penilaian yang lain agar dapat diukur dengan beragam penilaian.

\section{DAFTAR PUSTAKA}

Arikunto. (2010) Prosedur Penelitian Suatu Pendekatan Praktek. Jakarta: Rineka Cipta.

Arsyad, Azhar. (2014). Media Pembelajaran. (Jakarta: PT Raja Grafindo Persada Cet-17.

Aqib, Zainal. (2013). Model-model, Media dan Strategi Pembelajaran Kontekstual (Inovatif). (Bandung:Yrama Widya.

Choiroh, Uchi Nur Uzzlifatul. (2019). Peningkatan Kemampuan Berhitung Siswa Menggunakan Media Stick Pouch Materi Perkalian dan Pembagian Kelas li Mi At Taqwa Kraton Pasuruan. Skripsi Program Studi PGMI. Dakultas Tarbiyah dan Keguruan. UIN Sunan Ampel Surabaya. Tidak Terbit.

Daniati, Vera, Yuliasma \& Iriani, Z. 2013. Peningkatan Hasil Belajar Siswa dengan Model Kooperatif Tipe Snowball Throwing pada Pembelajaran Seni Tari Kelas VIIIC diSMPN 1 Bukittinggi. E-Jurnal Sendratasik FBS Universitas Negeri Padang. 2 (1). Diunduh pada laman http://ejournal.unp.ac.id/index.php/sendrat asik/article/view/2434/2046, pada Selasa, 6 Oktober 2020, Pukul 20.10 WIB

Departemen Pendidikan Nasional. (2007). Pedoman Pembelajaran Permainan Berhitung Permulaan Di Taman Kanak-Kanak. Jakarta: Direktorat Pembinaan TK dan SD.

Diantama, Suarifqi. (2018). Metode Penelitian Pendidikan. Bandung: Pustaka Rahmat

Dimyati \& Mudjiono. 2013. Belajar dan Pembelajaran. Jakarta: Rineka Cipta.

Fathurrohman, Pupuh dan Sobry Sutikno. 2007. Strategi Belajar Mengajar. Bandung: PT Refika Aditama

Idrus, Muhammad. (2011). Metode Penelitian Ilmu Sosial Pendekatan Kualitatif dan Kuantitatif. Jakarta: Erlangga.

Kustandi, Cecep dan Sutjipto, Bambang. (2013). Media Pembelajaran; Manual dan Digital, Bogor: Ghalia Indonesia. Hal.24

Kustiawan, Usep. (2016). Pengembangan Media Pembelajaran Anak Usia Dini. Penerbit Gunung Samudera, Malang 
Larasati Nur Indah Prawesti dan Mustika Dewi. Efektivitas Penggunaan Media Stick Pouch (Kantong Stik) Sebagai Media Pengembangan Kemampuan Kognitif Mengenal Konsep Bilangan 1-10 Anak $\mathrm{Tk}$

Ma'rifah. (2014). Upaya Meningkatkan Berhitung Permulaan Menggunakan Permainan Stick Angka Di Kelompok A Tk Dharma Wanita Persatuan Meduran Manyar Gresik. Pengembangan Profesional Keguruan. Gresik: Tidak Diterbitkan.

Moleong, Lexy J. 2006. Metodologi Penelitian Kualitatif. Edisi Revisi. Bandung: Remadja Karya

Mulyaningsih, Yenis Astina. (2016). Bermain Stick Angka Untuk Meningkatkan Kemampuan Berhitung Permulaan Pada Anak Kelompok B Di TK Desa Wonolopo Tasikmadu Karanganyar Tahun Ajaran 2015-2016. Skripsi Program Studi Pendidikan Anak Usia Dini Fakultas Keguruan dan Ilmu Pendidikan Universitas Muhammadiyah: Surakarta. Tidak Terbit

Mulyasa. (2013). Manajemen Paud. Bandung. PT. Remaja Rosdakarya.

Mursid. (2015). Pengembangan Pembelajaran PAUD. Bandung: PT.Remaja Rosdakarya.

Nasir, M. (1998). Metode Penelitian. Jakarta: Ghalia Indonesia.

Sapayona Z, Arini. (2019). Pengaruh Kegiatan Bermain Stik Angka Terhadap Kemampuan Berhitung Permulaan Pada Anak Usia 5-6 Tahun. Skripsi tidak diterbitkan. Bandar Lampung: UNILA

Shoimin, Aris. (2013). 68 Model Pembelajaran Inovatif Dalam Kurikulum 2013. Yogyakarta: Ar-ruz Media.

Suarifqi, Diantama. (2018). Metode Penelitian Pendidikan. Bandung: Pustaka Rahmat

Sugiyono. (2011) Metode Penelitian Kuantitatif Kualitatif R\&D. Bandung: Alfabeta

Sumani, Mukhlas. (2011). Belajar dan pembelajaran. PT.Remaja Rosdakarya, Bandung

Sumiyati dan Daryati. (2017). Upaya Meningkatkan Kemampuan Anak Belajar Berhitung Permulaan Melalui Media Kantong Stik di TK Bhakti Masyarakat Pagerharjo Pati. Jurnal Indonesian Journal of Islamic Early Childhood Education. Diunduh pada laman http://journal.pps-

pgra.org/index.php/ljiece/article/view/8o/4 6, pada Selasa, 6 Oktober 2020, Pukul 20.05 WIB

Sunhaji. (2014). Konsep Manajemen Kelas dan Implikasinya dalam Pembelajaran. Jurnal

(C) 2021, JoEE, Jurnal of Early Childhood. PGPAUD

e-ISSN: 2775-7870
Kependidikan, Vol. II No. 2 November 2014.

Susanto, Ahmad. (2011). Perkembangan Anak Usia Dini. Jakarta: Kencana Pernada MediaGroup.

Supartini. (2012). Upaya Meningkatkan Kemampuan Berhitung Pengurangan Dengan Teknik Meminjam Melalui Penerapan Media Kantong Nilai Pada Siswa Kelas II SDN Majenang II Kecamatan Sukodono Kabupaten Sragen Tahun Pelajaran 2011/2012. Skripsi Program Studi PPKHBPGSD Fakultas Keguruan dan Ilmu Pendidikan Universitas Sebelas Maret: Surakarta. Tidak Terbit

Trisnawati, Eki. (2018). Penerapan Strategi Bermain Stick Angka Dalam Meningkatkan Kemampuan Berhitung Permulaan Anak Di Paud Witri 1 Kota Bengkulu. Skripsi Program Studi Pendidikan Islam Anak Usia Dini Fakultas Tarbiyah dan Tadris, Institut Agama Islam Negeri: Bengkulu. Tidak Terbit

Winda, Lilis, Azizah. (2014). Metode Pengembangan Prilaku, dan Kemampuan Dasar Anak Usia Dini. Universitas Terbuka: Jakarta.

Zaman, Badru dkk. 2012. Media dan Sumber Belajar TK. Universitas Terbuka: Tangerang Selatan. 